\title{
PERAN DAN KOMPETENSI KEMAMPUAN PEMERINTAH TERHADAP PERKEMBANGAN EKONOMI DAN KESEJAHTERAAN MASYARAKAT DI KOTA BATAM
}

\author{
Ade Parlaungan Nasution
}

\begin{abstract}
This research had a purpose To (1). analysed and proved the influence of the government capacity on the development of Batam City economics (2) To analyse and prove the influence of the government capacity on the level of welfare in the Batam City (3) To measure and prove the influence of the Development of economics on Welfare of the Kota Batam Data Community that in used in this research was the secondary quantitative data.

The data was analysed by using the PLS analysis (partial Least Square).

Results that were received were the Goverment Capacity of the Batam City to be influential significant towards Welfare of the community was to be accepted.

Results of the PLS analysis produced the path coefficient 0.0500 with $p$-value $=0,000$, therefore was significant.

This means that was gotten by the influence of the significant negative between the Level of the government capacity towards welfare of the community.

The level of the Development of Kota Batam Economics was influential significant towards the level of welfare of the community was to be accepted.

Results of the PLS analysis produced the path coefficient 0.0500 with p-value $=0,000$, therefore significant.

This means that was gotten by the significant influence between the level of the development of economics towards the level of welfare of the City community Batam. Tingkat the government capacity was influential significant towards the level of the development of economics.

Results of the PLS analysis produced the path coefficient 0.0991 with $p$-value $=0,0001$, therefore was severed significant.
\end{abstract}

Keyword : Capacity, Welfare, Development, Batam City

\section{PENDAHULUAN}

Keberhasilan mengembangkan Batam sebagai daerah industri, perdagangan, galangan kapal dan pariwisata sejak dikeluarkannya Keppres No 41 tahun 1973 dan Keppres No 05 tahun 1983 tidak bisa disangkal lagi oleh siapapun juga.

Batam yang sebelumnya daerah kecil yang hanya dihuni oleh sekitar 6.000 jiwa, kini tampil sebagai daerah industri bertaraf Internasional dengan 460 Penanaman Modal Asing (PMA) dan tidak kurang dari 1.440 Penanaman Modal Dalam Negeri (PMDN) dengan nilai investasi mencapai 6,8 milliar dolar AS. 
Tidak salah, jika Pemerintah Pusat menjadikan Batam sebagai lokomotif perekonomian nasional yang kini sedang melakukan pemulihan ekonomi (recovery). Diproyeksikan, hingga akhir tahun 2007 ini kontribusi dari pajak penghasilan sebesar Rp 5 triliun dan diharapkan target pertumbuhan ekonomi Batam tahun ini sebesar 4,5 persen bisa diwujudkan.

Akan tetapi, keberhasilan sektor ekonomi secara makro di Batam seperti itu belum disertai dengan meningkatnya kesejahteraan warganya, ratusan ribu warga Batam masih tinggal di rumah-rumah liar yang kumuh dengan anak-anak usia sekolah yang terpaksa harus bekerja membantu meringankan beban orang tuanya. Hal ini antara lain disebabkan belum cukupnya akses warga Batam untuk aktif terlibat dalam kegiatan ekonomi sektor formal yang menuntut berbagai persyaratan tertentu seperti keterampilan dan pendidikan

Dengan semakin berhasilnya pembangunan yang diselenggarakan pemerintah Kota Batam, kemampuan masyarakat dan swasta juga semakin meningkat, baik dalam merencanakan dan melaksanakan kegiatan fisik/proyek maupun kemampuan dana untuk membiayainya. Sedangkan di lain pihak, kemampuan dana pemerintah semakin menurun. Dengan demikian, perencanaan pembangunan khususnya perencanaan kegiatan fisik/proyek, juga semakin bergeser ke masyarakat dan swasta.

Pertama, kegiatan fisik pemerintah daerah semakin menurun dan terbatas hanya pada penyediaan public goods, seperti air minum, tenaga listrik, telepon, sekolah, dan rumah sakit/puskesmas.

Kedua, karena sebagian besar kegiatan fisik pembangunan berada di tangan masyarakat/swasta, untuk menjamin bahwa kegiatan masyarakat itu secara menyeluruh akan mengarah pada sesuatu yang kita inginkan bersama, maka diperlukan suatu kesepakatan mengenai tujuan umum ke mana pembangunan bangsa ini mengarah atau suatu visi mengenai masa depan.

Ketiga, karena sebagian besar kegiatan fisik pembangunan sudah berada di tangan masyarakat/swasta, maka masyarakat/swasta sekarang berada di depan sebagai pelopor pembangunan dan pemerintah lebih berperan sebagai fasilitator pembangunan 
bukan saja dengan menyediakan public goods, tetapi juga melalui kebijakan publik untuk mengarahkan dan mendukung kegiatan masyarakat/swasta.

Tabel 1.1

RASIO JUMLAH TENAGA KERJA DENGAN JUMLAH PENDUDUK DI KOTA BATAM TAHUN 2001 - 2005

\begin{tabular}{|l|l|l|l|}
\hline Tahun & Tenaga Kerja & Penduduk & Rasio \\
\hline 2001 & 159.550 & 437.358 & 0,365 \\
2002 & 175.226 & 532.990 & 0,329 \\
2003 & 187.842 & 562.661 & 0,334 \\
2004 & 224.260 & 596.123 & 0,376 \\
2005 & 224.555 & 685.787 & 0.327 \\
\hline
\end{tabular}

Sumber: Dinas Tenaga Kerja Kota Batam 2006

Sebagaimana hasil keputusan politik yang menjadikan Batam sebagai pusat pengembangan industri, perkembangan industrialisasi di Batam maju sangat pesat. Akibatnya Batam berkembang menjadi sentra ekonomi yang sangat kuat dan menjadi magnet bagi masyarakat untuk ikut "mengundi nasib" di Batam. Bagai pepatah "ada gula ada semut" , maka Batam berubah menjadi semacam "gula" yang kemudian banyak menyedot "semut".

Gambar 1.1

PERKEMBANGAN JUMLAH PENDUDUK KOTA BATAM TAHUN 2000 - 2005 


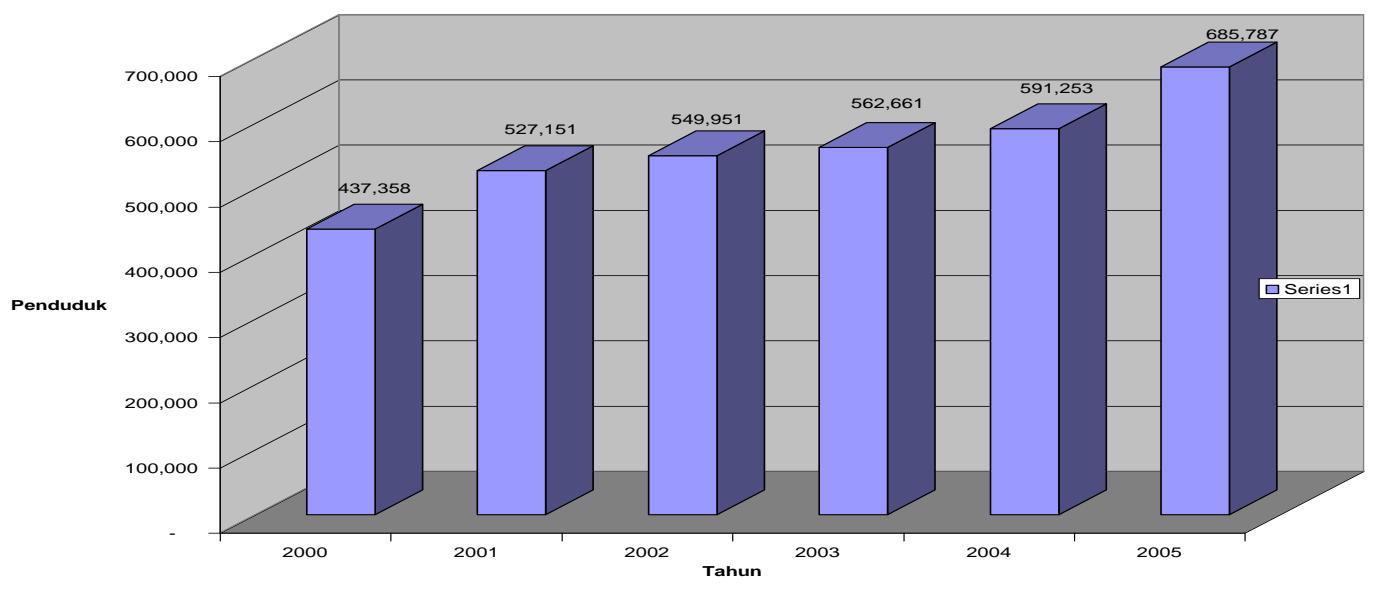

Batam kemudian berkembang menjadi daerah tujuan pencari kerja utama selain Jakarta, baik yang datang dari daerah yang jauh dari Batam maupun daerah di sekitar P. Batam termasuk masyarakat di kawasan hinterland.

Dari data yang dikeluarkan Otorita Batam (OB) tahun 2004 diperoleh gambaran jumlah investasi saat ini mencapai 32 Juta dolar AS. Jumlah investasi sebesar itu berasal dari pemerintah 20 persen, 47 persen dari swasta domestik, dan 33 persen investasi swasta asing. Dari nilai investasi yang ditanamkan pihak swasta sektor industri menjadi primadona yang menyerap tak kurang 50 persen. Menyusul kemudian investasi di bidang perdagangan dan jasa, perumahan, pariwisata, dan baru kemudian pertanian termasuk di dalamnya sub sektor perikanan termasuk perikanan laut.

Secara lengkap kegiatan perekonomian Batam yang mencerminkan struktur ekonomi di kawasan ini adalah 71,60 \% merupakan industri pengolahan, 11,13\% perdagangan, hotel dan restoran, 4,90 \% sektor keuangan, 3,47 \% aktivitas ekonomi di bidang pengangkutan dan komunikasi, 3,28 \% bangunan, 1,99 \% bergerak di bidang jasa-jasa dan 1,62 \% aktivitas ekonomi pertanian (BPS Batam, 2004).

Memang dari data perikanan yang ada, yang nilai produksi perikanan tangkap pada tahun 2005 sebesar 8.280.000 kg di mana kawasan Belakang Padang memasok 4.020.620 kg sendiri (49 \%) dengan nilai total rupiah sekitar 29,46 milyar, namun harus diberi catatan bahwa bagian terbesar yang menikmati hasil itu bukanlah nelayan tetapi para pedagang.

Kemudian perlu dikemukakan bahwa bahan baku yang dipergunakan untuk keperluan industri diimpor (85,33 persen dari impor Batam) dari negara Singapura, Jepang, AS, Perancis, Thailand dan sebagainya 
. Sedangkan 1900 perusahaan yang terdapat di Batam, lebih dari seperempat bergerak di sektor industri berat, sedang (521 perusahaan) seperti industri peralatan pengeboran lepas pantai, komponen elektronika, bahan kimia untuk farmasi dan migas, tekstil, pipa baja, alat-alat optik dan galangan kapal, sepatu, komputer dan komponennya. Di sektor perdagangan dan perhotelan terdapat 532 perusahaan.

Dengan demikian tidak mengherankan bila kegiatan perekonomian Batam yang didominasi sektor industri yang berorientasi ekspor (sekitar 70 persen) sebagaimana tergambar dalam struktur Pendapatan Domestik Regional Bruto (PDRB) Kota Batam menjadikan Batam sebagai kota yang kaya, maju dan modern dengan nilai total kegiatan ekonominya pada tahun 1999 mencapai 5,89 trilyun rupiah. Sedangkan masyarakat dengan sistem dan struktur perekonomian seperti tersebut tidak dapat mengakses ke dalamnya. Dengan sistem dan struktur perekonomian yang demikian tidak ada pasokan bahan baku yang bisa disediakan oleh masyarakat sehingga tidak ada linkage ekonomi antara Batam sebagai kawasan bonded dengan kawasan hinterland Batam.

Memang muncul argumen perkembangan perekonomian Batam yang demikian akan memberikan economic multiplier effect bagi kawasan hinterland Batam. Namun yang dipertanyakan masyarakat kawasan hinterland adalah bahwa efek ekonomi yang diperoleh tidaklah sebanding dengan apa yang dicapai di Batam.. Demikian pula argumen bahwa kemajuan Batam akan memberikan peluang kesempatan kerja bagi masyarakat layak dipertanyakan Kemudian perlu dikemukakan bahwa bahan baku yang dipergunakan untuk keperluan industri diimpor (85,33 persen dari impor Batam) dari negara Singapura, Jepang, AS, Perancis, Thailand dan sebagainya

Terabaikannya kesejahteraan Masyarakat Batam nampaknya bukan hanya "kealpaan" by design yang kemudian menciptakan sistem dan struktur ekonomi Batam yang terpisah antara Pembangunan ekonomi dan Kesejahteraan masyarakat tetapi nampaknya juga berkaitan dengan faktor-faktor kultural serta psiko budaya masyarakat itu sendiri. 
Tabel 1.4

PERKEMBANGAN JUMLAH TENAGA KERJA KOTA BATAM TAHUN 2005

\begin{tabular}{|c|c|c|c|c|c|c|c|c|}
\hline & \multirow{3}{*}{ Sektor } & \multicolumn{6}{|c|}{ Desember 2005} & \multirow{3}{*}{$\begin{array}{l}\text { WNI + } \\
\text { WNA }\end{array}$} \\
\hline & & \multicolumn{3}{|c|}{ WNI } & \multicolumn{3}{|c|}{ WNA } & \\
\hline & & $\mathbf{L}$ & $\mathbf{P}$ & $L+P$ & $\mathbf{L}$ & $\mathbf{P}$ & $L+P$ & \\
\hline 1 & Pertanian & 1.568 & 192 & 1.760 & - & - & - & 1.760 \\
\hline 2 & $\begin{array}{l}\text { Pertambangan dan } \\
\text { Penggalian }\end{array}$ & 484 & 241 & 725 & 16 & - & 16 & 741 \\
\hline 3 & Industri & $\begin{array}{c}53.26 \\
1\end{array}$ & $\begin{array}{c}117.67 \\
1\end{array}$ & $\begin{array}{c}170.93 \\
2\end{array}$ & $\begin{array}{c}2.87 \\
6\end{array}$ & $\begin{array}{c}14 \\
9\end{array}$ & $\begin{array}{c}3.02 \\
5\end{array}$ & 173.957 \\
\hline 4 & $\begin{array}{c}\text { Listrik, Gas dan Air } \\
\text { Bersih }\end{array}$ & 1.035 & 186 & 1.221 & 4 & - & 4 & 1.225 \\
\hline 5 & Bangunan & $\begin{array}{c}17.72 \\
9\end{array}$ & 1.290 & 19.019 & 5 & - & 5 & 19.024 \\
\hline 6 & $\begin{array}{c}\text { Perdagangan, Hotel } \\
\text { dan Restoran }\end{array}$ & $\begin{array}{c}11.93 \\
8\end{array}$ & 4.324 & 16.262 & 60 & - & 60 & 16.322 \\
\hline 7 & $\begin{array}{c}\text { Pengangkutan dan } \\
\text { Komunikasi }\end{array}$ & 1.495 & 1.471 & 2.966 & 31 & - & 31 & 2.997 \\
\hline 8 & $\begin{array}{c}\text { Keuangan, Jasa } \\
\text { Persewaan dan } \\
\text { Perusahaan }\end{array}$ & 1.927 & 609 & 2.536 & 2 & - & 2 & 2.538 \\
\hline 9 & Jasa-jasa & 5.125 & 845 & 5.970 & 15 & 6 & 21 & 5.991 \\
\hline & Jumlah & $\begin{array}{c}94.56 \\
2\end{array}$ & $\begin{array}{c}126.82 \\
9\end{array}$ & $\begin{array}{c}221.39 \\
1\end{array}$ & $\begin{array}{c}3.00 \\
9\end{array}$ & $\begin{array}{c}15 \\
5\end{array}$ & $\begin{array}{c}3.16 \\
4\end{array}$ & 224.555 \\
\hline
\end{tabular}

Sumber: Badan Pusat Statistik Kota Batam, 2005

\subsection{Rumusan Masalah}

Berdasarkan latar belakang dan judul proposal penelitian disusun rumusan masalah sebagai berikut : 
1. Apakah Kemampuan Pemerintah berpengaruh signifikan terhadap Perkembangan Ekonomi Kota Batam ?

2. Apakah Kemampuan Pemerintah berpengaruh signifikan terhadap Kesejahteraan Masyarakat Kota Batam ?

3. Apakah Perkembangan Ekonomi berpengaruh signifikan terhadap Kesejahteraan Masyarakat di Kota Batam ?

\section{Metodologi Penelitian}

\subsection{Variabel Penelitian}

Sesuai dengan tujuan dan obyek penelitian yang dirumuskan maka variable yang akan diteliti adalah sebagai berikut :

1. Variabel laten (X1) yang merupakan variabel kemampuan pemerintah dibentuk oleh indikator-indikator : Pendapatan Asli Daerah (PAD) dan Belanja Pembangunan APBD Kota Batam..

2. Variabel laten (X2) yang merupakan tingkat perkembangan ekonomi dibentuk oleh indikator-indikator : Tingkat Produk Domestik Regional Bruto (PDRB) dan Tingkat Penyerapan tenaga kerja .

3. Variabel dependen, yaitu Kesejahteraan masyarakat (Y), dengan indikator indikator : tingkat pendidikan, tingkat kesehatan dan tingkat daya beli/pendapatan.

4.3.1. Identifikasi dan klasifikasi Variabel
1) Variabel Independen : Kemampuan Pemerintah
2) Variabel Intervening : Perkembangan Ekonomi
3) Variabel Dependen : Kesejahteraan Masyarakat

\subsubsection{Definisi Operasional Variabel.}

Kemampuan Pemerintah merupakan merupakan suatu keadaan dimana pemerintah mempunyai kemampuan untuk belanja modal dalam Anggaran Pendapatan dan Belanja Daerah (APBD) yang mampu mempengaruhi perkembangan ekonomi dan 
kesejahteraan masyarakat. Berdasarkan atas hal tersebut penulis memunculkan indikator-indikatorl berikut sebagai ukuran Kemampuan Pemerintah.

$$
\begin{aligned}
& \mathrm{X} 1=\text { Pendapatan Asli Daerah (PAD) } \\
& \mathrm{X} 2=\text { Belanja Modal Pemerintah Kota Batam }
\end{aligned}
$$

Variabel Perkembangan Ekonomi Kota Batam ini diukur dengan 2 (dua) indikator yaitu :

Y11 = Pertumbuhan Ekonomi

Y12 = Penyerapan Tenaga Kerja

Kesejahteraan Masyarakat adalah merupakan suatu bentuk perbaikan kehidupan masyarakat sebagai akibat dari kebijakan pemerintah dan proses pembangunan masyarakat. Variable ini diukur dengan 4 (empat) indikator yaitu :

Y2.1 = Tingkat Pendidikan

Y2.2 = Tingkat Kesehatan

Y2.3 =Tingkat Daya Beli/Pendapatan

Adapun definisi operasional dalam penelitian ini adalah sebagai berikut :

1. Kemampuan Pemerintah merupakan merupakan suatu keadaan dimana pemerintah mempunyai kemampuan untuk belanja modal dalam Anggaran Pendapatan dan Belanja Daerah (APBD) yang mampu mempengaruhi perkembangan ekonomi dan kesejahteraan masyarakat

2. Kebijakan pemerintah adalah suatu tindakan rekayasa dan pembangunan sosial ekonomi.

3. Kesejahteraan Masyarakat adalah merupakan suatu bentuk perbaikan kehidupan masyarakat sebagai akibat dari kebijakan pemerintah dan proses pembangunan masyarakat

\subsection{Metode Pengumpulan Data}

Didalam penelitian ini untuk mendapatkan informasi yang relevan digunakan metode pengumpulan data yang dilakukan yaitu :

a. Wawancara yaitu metode pengumpulan data yang dilakukan penulis dengan cara tanya jawab dengan para responden. 
b. Kuisioner yaitu metode pengumpulan data dilakukan dengan memberikan daftar pertanyaan kepada responden untuk mendapatkan informasi tentang variable-variabel yang diteliti.

\subsection{Metode Analisis Data}

Model analisis data digunakan adalah analisis PLS (Partial Least Square) dengan menggunakan bantuan program komputer paket SmartPLS, dengan alasan bahwa :

1. Model analisisnya berjenjang dan model persamaan structural memenuhi model rekursif.

2. Variabelnya laten

3. Sample size - nya kecil dan tidak memenuhi untuk menggunakan SEM (Structural Equation Model)

\subsection{Hasil Analisis Deskriptif}

\subsubsection{Kemampuan Daerah}

Tabel 5.12

BESARNYA PENDAPATAN ASLI DAERAH (PAD) KOTA BATAM DAN TOTAL BELANJA DAERAH TAHUN 2001-2005 (DALAM JUTAAN RUPIAH)

\begin{tabular}{|c|c|r|r|r|r|r|}
\hline No & Uraian & 2001 & 2002 & 2003 & 2004 & \\
\hline 1 & Total PAD Batam & $28,475.56$ & $50,613.52$ & $56,379.18$ & $63,334.99$ & $67,187.85$ \\
\hline 2 & $\begin{array}{c}\text { Total Belanja } \\
\text { Daerah }\end{array}$ & 310.455 .08 & $375.738,67$ & $365.108,55$ & $381.169,75$ & $353.762,79$ \\
\hline
\end{tabular}

Sumber : diolah

Tabel 5.14

BEBERAPA INDIKATOR EKONOMI BATAM

\begin{tabular}{|l|c|c|c|c|c|c|}
\hline \multicolumn{1}{|c|}{ Indikator } & Ket & $\mathbf{2 0 0 1}$ & $\mathbf{2 0 0 2}$ & $\mathbf{2 0 0 3}$ & $\mathbf{2 0 0 4}$ & $\mathbf{2 0 0 5}$ \\
\hline Investasi & Dalam dolar & 8,80 & 9,46 & 10,28 & 11,53 & 11,89 \\
\hline Perusahaan asing & Perusahaan & 531 & 611 & 688 & 750 & 813 \\
\hline Tenaga kerja & Orang & 161.648 & 170.192 & 185.095 & 221.163 & 221.391 \\
\hline
\end{tabular}




\begin{tabular}{|l|c|c|c|c|c|c|}
\hline Indonesia & & & & & & \\
\hline Tenaga kerja asing & Orang & 2.116 & 2.517 & 2.747 & 3.097 & 2.988 \\
\hline
\end{tabular}

Sumber : Otorita Batam

\subsubsection{Kesejahteraan Masyarakat}

Tabel 5.15

INDEK PEMBANGUNAN MANUSIA (IPM) KOTA BATAM

TAHUN 2001-2004

\begin{tabular}{|c|l|c|c|c|c|c|}
\hline No. & \multicolumn{1}{|c|}{ Komponen IPM } & $\mathbf{2 0 0 1}$ & $\mathbf{2 0 0 2}$ & $\mathbf{2 0 0 3}$ & $\mathbf{2 0 0 4}$ & 2005 \\
\hline 1. & Angka harapan hidup (th) & 69,30 & 71,45 & 71,96 & 72,01 & 72,46 \\
2. & Rata-rata lama sekolah (th) & 9,10 & 9,90 & 10,20 & 10,80 & 12,01 \\
3. & Angka melek huruf (\%) & 96,30 & 97,16 & 97,77 & 98,28 & 98,78 \\
4. & Daya Beli (Rp) & 483.091 & 522.764 & 525.378 & 552.974 & 573.209 \\
\hline
\end{tabular}

Sumber : BPS Kota Batam (diolah)

\section{Hasil Pengujian Hipotesis}

Tabel 5.16

HASIL PENGUJIAN HIPOTESIS

\begin{tabular}{|c|l|l|c|c|l|}
\hline No & Variabel Independen & $\begin{array}{c}\text { Variabel } \\
\text { Dependen }\end{array}$ & $\begin{array}{c}\text { Koefisien } \\
\text { Jalur inner } \\
\text { weight }\end{array}$ & P-Value & Keterangan \\
\hline 1 & $\begin{array}{l}\text { Kemampuan } \\
\text { Pemerintah }\end{array}$ & $\begin{array}{l}\text { Perkembangan } \\
\text { Ekonomi }\end{array}$ & 0,0991 & 0.001 & Signifikan \\
\hline 2 & $\begin{array}{l}\text { Kemampuan } \\
\text { Pemerintah }\end{array}$ & $\begin{array}{l}\text { Kesejahteraan } \\
\text { Masyarakat }\end{array}$ & 0,0501 & 0.000 & Signifikan \\
\hline 3 & $\begin{array}{l}\text { Perkembangan } \\
\text { Ekonomi }\end{array}$ & $\begin{array}{l}\text { Kesejahteraan } \\
\text { Masyarakat }\end{array}$ & 0,0501 & 0.000 & Signifikan \\
\hline
\end{tabular}




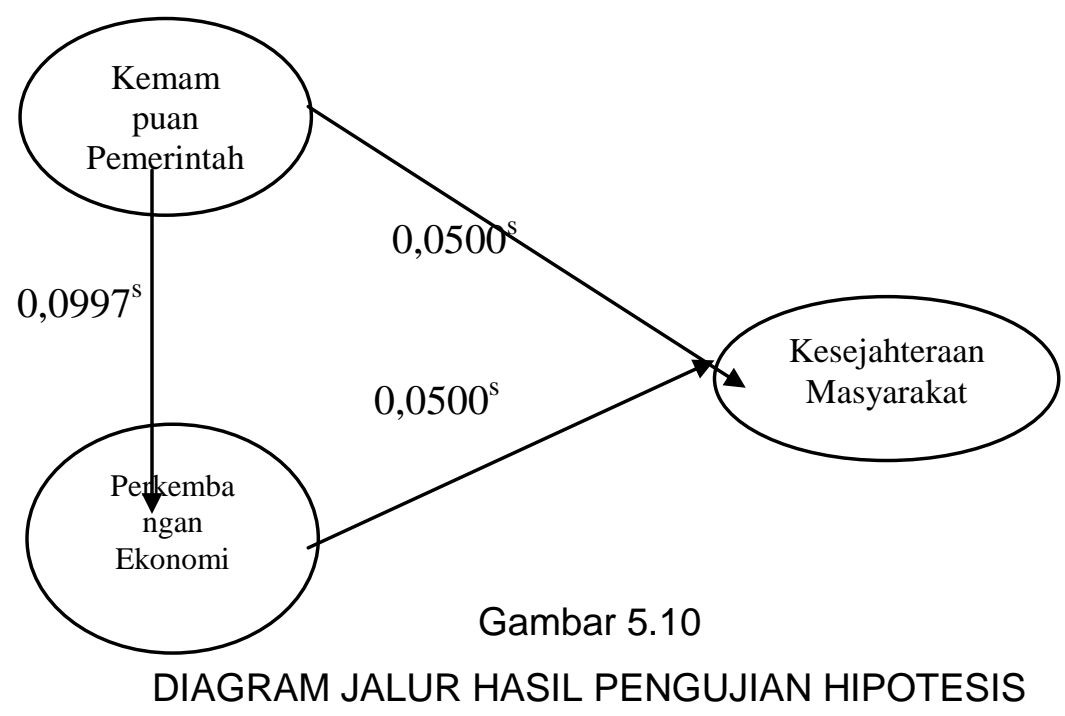

Berdasarkan Tabel 5.17 dan Gambar 5.1 maka diperoleh hasil pengujian hipotesis sebagai berikut:

1. Kemampuan Pemerintah Kota Batam berpengaruh signifikan terhadap Kesejahteraan masyarakat adalah diterima. Hasil analisis PLS menghasilkan koefisien jalur 0,0500 dengan $p$-value $=0.000$, dengan demikian diputuskan signifikan. Berarti terdapat pengaruh negatif signifikan antara Tingkat kemampuan pemerintah terhadap kesejahteraan masyarakat, dimana bila tingkat tingkat kemampuan pemerintah meningkat maka akan diikuti oleh kenaikan tingkat kesejahteraan masyarakat kota Batam.

2. Tingkat Perkembangan Ekonomi Kota Batam berpengaruh signifikan terhadap tingkat kesejahteraan masyarakat adalah diterima. Hasil analisis PLS menghasilkan koefisien jalur 0,0500 dengan $p$-value $=0.000$, dengan demikian diputuskan signifikan. Berarti terdapat pengaruh signifikan antara tingkat perkembangan ekonomi terhadap tingkat kesejahteraan masyarakat Kota Batam.

3. Tingkat kemampuan pemerintah berpengaruh signifikan terhadap tingkat perkembangan ekonomi. Hasil analisis PLS menghasilkan koefisien jalur 0,0997 
dengan $\mathrm{p}$-value $=0.0001$, dengan demikian diputuskan signifikan. Berarti terdapat pengaruh signifikan antara tingkat kemampuan pemerintah terhadap perkembangan ekonomi di kota Batam.

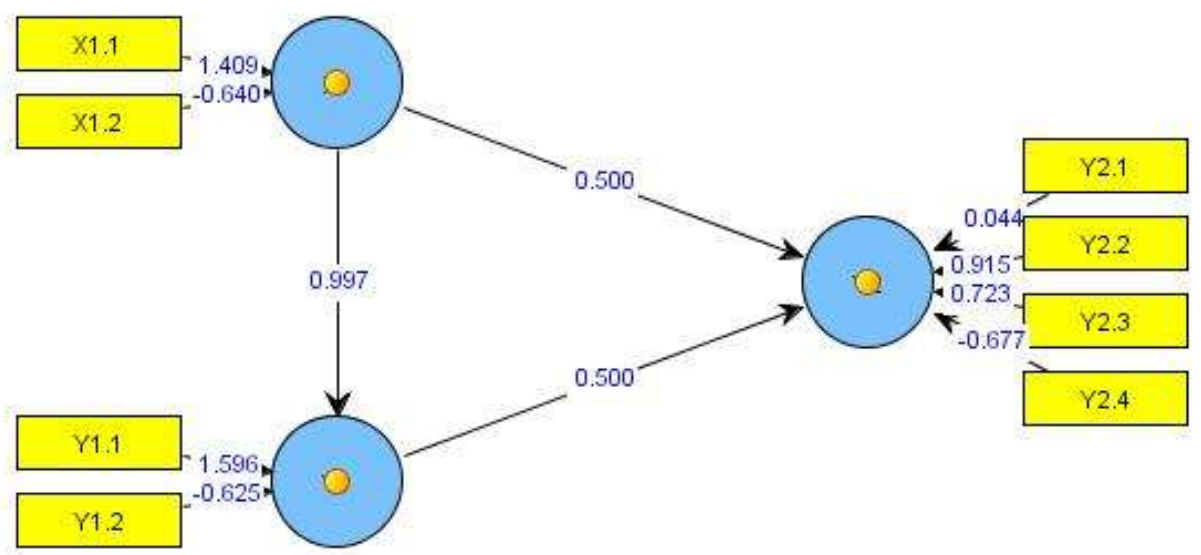

\section{PEMBAHASAN}

PENGARUH KEMAMPUAN PEMERINTAH TERHADAP PERKEMBANGAN EKONOMI KOTA BATAM

Tingkat kemampuan pemerintah berpengaruh signifikan terhadap tingkat perkembangan ekonomi. Hasil analisis dengan menggunakan metode Partial Least Square (PLS) menghasilkan koefisien jalur 0,0997 dengan $p$-value $=0.0001$, dengan demikian diputuskan signifikan. Berarti terdapat pengaruh signifikan antara tingkat kemampuan pemerintah terhadap perkembangan ekonomi di kota Batam.

Kemampuan pemerintah yang tercermin dalam Pendapatan Asli Daerah (PAD) dan besarnya belanja pembangunan, mempunyai multifflier effect terhadap tingkat perkembangan ekonomi. Melalui kemampuan pemerintah diharapkan dapat meningkatkan efisiensi, efektivitas, dan akuntabilitas sektor publik di Kota Batam Hasil analisis dengan menunjukkan ternyata kontribusi PAD (Pendapatan Asli Daerah) terhadap pertumbuhan ekonomi daerah cukup signifikan. Rasio PAD (Pendapatan Asli Daerah) Kota Batam PDRB dalam tahun 2004 adalah 0.0028 dan pada tahun 2005 meningkat menjadi 0,0031 \%. Peningkatan kontribusi PAD (Pendapatan Asli Daerah) terhadap pertumbuhan ekonomi daerah bersifat tidak langsung, yaitu melalui fungsi 
konsumsi. Artinya meningkatnya jumlah uang yang beredar di daerah, maka tingkat konsumsi juga meningkat .

Sejalan dengan tugas yang diemban oleh Pemerintah Daerah, dalam jangka panjang peningkatan PAD (Pendapatan Asli Daerah) diharapkan mampu memberikan stimulus terhadap pertumbuhan perekonomian daerah. Kondisi seperti ini akan tercapai apabila kebijakan-kebijakan yang dilakukan oleh Pemerintah Daerah dapat mendorong berkembangnya dunia usaha. Dengan berkembangnya perekonomian daerah, maka dampak positif juga akan dinikmati oleh Pemerintah Kota Batam dalam bentuk penyerapan tenaga kerja, peningkatan PAD dan lain sebagainya, sehingga akan bermuara pada peningkatan kesejahteraan masyarakat

\subsection{PENGARUH KEMAMPUAN PEMERINTAH TERHADAP KESEJAHTERAAN MASYARAKAT}

Kemampuan Pemerintah Kota Batam berpengaruh signifikan terhadap Kesejahteraan masyarakat adalah diterima. Hasil analisis PLS menghasilkan koefisien jalur 0,0500 dengan $\mathrm{p}$-value $=0.000$, dengan demikian diputuskan signifikan. Berarti terdapat pengaruh negatif signifikan antara Tingkat kemampuan pemerintah terhadap kesejahteraan masyarakat, dimana bila tingkat tingkat kemampuan pemerintah meningkat maka akan diikuti oleh kenaikan tingkat kesejahteraan masyarakat kota Batam.

Di Kota Batam, kemampuan pemerintah dalam hal belanja pembangunan seperti pembangunan sarana dan prasarana seperti pembangunan sekolah, rumah sakit/puskesmas, bantuan permodalan usaha kecil ternyata berpengaruh signifikan terhadap kesejahteraan masyarakat yang mempunyai indikator terhadap naiknya tingkat pendapatan masyarakat, tingkat kesehatan, tingkat pendidikan dan tingkat kriminalitas.

Pemerintah Kota Batam melalui kebijakan belanja pembangunan dapat memberikan peningkatan pendapatan yang memadai dan mendidik masyarakat untuk mengelola kegiatan secara ekonomis, hasilnya dapat dilestarikan oleh masyarakat sendiri sehingga menciptakan pemupukan modal dalam wadah lembaga sosial ekonomi setempat, memperkuat kelembagaan keuangan daerah yang dapat mendorong pengembangan dan pelestarian bantuan, yaitu : 
Bantuan pembangunan dari Pemerintah Kota Batam diarahkan untuk menciptakan dan memperluas lapangan kerja, kesempatan berusaha, serta meningkatkan partisipasi masyarakat dalam pembangunan, untuk itu pelaksanaan proyek-proyek pembangunan diprioritaskan bagi penduduk setempat terutama golongan usaha ekonomi lemah. Sedapat mungkin pelaksanaan dari proyek pembangunan dilakukan oleh masyarakat melalui wadah LKMD atau dalam bentuk kerjasama operasional (KSO) antara masyarakat (LKMD) dengan kontraktor setempat.

Disamping itu juga diarahkan kepada penciptaan iklim yang sehat untuk berkembangnya dunia usaha terutama bagi usaha masyarakat dan indutri kecil, yaitu : membuka tempat pemasaran di setiap ibukota kecamatan dan pusat-pusat pertumbuhan

Peningkatan IPM Kota Batam diharapkan dapat terus berlanjut pada periodeperiode berikutnya, dan ini tentunya tidak akan terlepas dari berbagai upaya yang harus tetap dijalankan untuk perbaikan variabel indikator IPM, sehingga secara keseluruhan

diharapkan dapat memberikan stimulasi terhadap kenaikan indikator IPM tidak saja dicerminkan dari kenaikan angka indeks semata, tetapi juga pada realita yang ada di lapangan.

\section{A. Angka Harapan Hidup}

Angka harapan hidup adalah rata-rata lamanya hidup yang akan dicapai oleh penduduk. Perkembangan indikator Angka Harapan Hidup di Kota Batam dari tahun 1999-2004 menunjukan adanya kenaikan. Meningkatnya angka harapan hidup di Kota Batam tidak terlepas dari upaya pemerintah kota dalam meningkatkan jumlah sarana maupun prasarana kesehatan, tenaga medis serta sarana-sarana lainnya dengan tujuan agar semua lapisan masyarakat dapat memperoleh pelayanan kesehatan secara mudah, merata dan murah.

Indikator angka harapan hidup sangat erat kaitannya dengan bidang kesehatan, meskipun angka harapan hidup yang telah dicapai oleh Kota Batam terus mengalami peningkatan. Namun ke depan masih ada sejumlah tantangan yang harus dihadapi untuk terus meningkatkan Angka Harapan Hidup, diantaranya masih diperlukannya perhatian yang intensif khususnya kepada perempuan, bayi, anak balita, dan lansia.

Secara kualitatif persepsi dan kemampuan masyarakat untuk dapat mengakses fasilitas kesehatan yang layak relatif belum begitu merata, terlebih lagi bagi keluarga 
miskin yang kemampuannya relatif sangat rendah untuk dapat mengakses fasilitas tersebut.

\section{Rata-rata Lama Sekolah (RLS) dan Angka Melek Huruf (AMH)}

Perkembangan RLS dan AMH dalam kurun waktu empat tahun terakhir mengalami kenaikan yang cukup berarti. Kenaikan Indikator ini sangat dipengaruhi oleh beberapa indikator yang terangkum dalam bidang pendidikan, seperti: indikator akses pendidikan (Angka Partisipasi Murni/ APM dan Angka Partisipasi Kasar/ APK) dan indikator mutu pendidikan (Angka Mengulang, Angka Putus Sekolah, dan Angka Lulusan). Hal Ini memperlihatkan bahwa beberapa indikator akses pendidikan dan mutu pendidikan diyakini mampu memberikan pengaruh dan atau kontribusi terhadap pencapaian indikator Angka Melek Huruf dan Rata-Rata Lama Sekolah.

Sampai dengan tahun ajaran 2004/2005, gambaran APM untuk tingkat pendidikan SD/MI adalah sebesar 83,23\%, SLTP/MTs sebesar 69,21\%, dan SMU/MA sebesar $52,75 \%$. Sedangkan untuk APK pada tahun ajaran yang sama untuk tingkat pendidikan SD/MI adalah sebesar 92,77\%, SLTP/MTs sebesar 79,70\%, dan SMU/MA sebesar $58,61 \%$.

Untuk sejumlah indikator mutu pendidikan menunjukkan, bahwa angka mengulang terbesar pada tahun ajaran 2004/2005 terdapat pada tingkat SLTP/MTs yaitu sebesar 20,00\% dan terendah terdapat pada tingkat SMU/MA yaitu sebesar $6,00 \%$, untuk SD/MI sebesar $16,00 \%$.

Angka putus sekolah terbesar terdapat pada tingkat pendidikan SD/MI yaitu sebesar 0,19\% sedangkan untuk tingkat SLTP/MTs dan SMU/MA tidak ada angka putus sekolah. Persentase angka kelulusan siswa pada tahun ajaran 2004/2005 di Kota Batam pada semua jenjang pendidikan menunjukan angka yang cukup mengembirakan yaitu di tingkat SD/MI sebesar 99,75\% di tingkat SLTP/MTs sebesar $81,19 \%$ dan untuk tingkat SMU/MA sebesar 99,44\%.

\section{Indeks Daya Beli}

Krisis ekonomi yang terjadi sejak pertengahan tahun 1997 telah berdampak langsung terhadap penurunan daya beli penduduk Kota Batam. Namun demikian setelah periode tahun 1999 telah terjadi kembali peningkatan daya beli penduduk. Indek 
daya beli meningkat cukup tajam pada periode 2002-2004, dengan laju pencapaian sebesar 1,78 persen per tahun.

Indeks daya beli lebih dikenal dengan kemampuan daya beli yang disesuaikan. Sebagaimana perkembangan indikator komposit lainnya, Indeks daya beli juga mengalami peningkatan dari tahun 1999-2004, dimana pada tahun 1999 Indeks daya beli sebesar Rp 483.091 pada tahun 2002 mengalami peningkatan menjadi sebesar Rp 522.764 pada tahun 2003 meningkat menjadi sebesar Rp 525.3781 dan pada tahun 2004 meningkat menjadi sebesar Rp 552.974.

Tantangan kedepan yang masih akan dihadapi, baik secara langsung maupun tidak langsung yang terkait dengan kemampuan daya beli masyarakat ini, diantaranya seperti :

1. Peningkatan jumlah produksi sektor usaha kecil,

2. Peningkatan efisiensi dalam proses produksi,

3. Pengembangan pola diversifikasi usaha,

4. Pembentukan kelompok masyarakat dalam memperkuat posisi tawar,

5. dan pembentukan jaringan dalam mendukung perluasan akses pasar.

\subsubsection{Rumah Tangga Miskin di Kota Batam}

Kemiskinan merupakan masalah utama pembangunan diberbagai bidang yang ditandai dengan kerentanan dibidang ekonomi, ketidakberdayaan dalam berusaha, keterisolasian dan ketidak-mampuan mengemukakan aspirasi untuk mengaktualisasikan diri dalam meningkatkan taraf hidup.

Dengan demikian dapat dikatakan bahwa pada dasarnya masyarakat miskin mempunyai ciri ketidakberdayaan atau ketidak mampuan (powerlessness) dalam hal : (a). memenuhi kebutuhan-kebutuhan dasar seperti pangan dan gizi, sandang, papan, pendidikan dan kesehatan; (b). melakukan kegiatan usaha produktif; (c). menjangkau akses sumber daya sosial dan ekonomi; (d). menentukan nasibnya sendiri serta senantiasa mendapatkan perlakuan diskriminatif, mempunyai perasaan ketakutan dan kecurigaan, serta sikap apatis dan fatalistis; dan (e). membebaskan diri dari mental dan budaya miskin serta senantiasa merasa mempunyai martabat dan harga diri yang rendah. 
Ketidakberdayaan itu kemudian menumbuhkan "Prilaku Miskin" yang bermuara pada hilangnya kemampuan untuk berusaha dan menikmati kesejahteraan secara bermartabat. Disamping itu kemiskinan juga disebabkan oleh karakteristik wilayah dan kondisi sosial masyarakat serta standar hidup.

Berpijak kepada gambaran kondisi kemiskinan yang ada, secara umum dapat diungkapkan bahwa penyebab kemiskinan di Kota Batam berkemungkinkan disebabkan oleh hal-hal sebagai berikut :

1. Keterbatasan Kesempatan Kerja dan Berusaha

2. Keterbatasan Akses terhadap faktor produksi

3. Rendahnya kepemilikan asset / kepemilikan terhadap asset tertentu

4. Keterbatasan akses terhadap fasilitas pendidikan

5. Terhambatnya mobilitas sosial dan kurangnya partisipasi

6. Lemahnya penyelenggaraan perlindungan sosial.

Jika dilihat dari kondisi rumah tangga miskin di Kota Batam, umumnya ditemui pada rumah tangga yang hidup dari sektor perikanan (nelayan) yang sangat tergantung pada alam. Selain daripada itu ditemui pada rumah tangga yang berasal dari kelompok buruh pabrik, dan penduduk yang datang sebagai migrasi yang tidak mempunyai keterampilan serta masyarakat yang mengalami pemutusan hubungan kerja.

Berdasarkan hasil Pendataan Sosial Ekonomi Tahun 2005 yang dilakukan di Kota Batam, dari jumlah penduduk Kota Batam pada tahun 2005 yang berjumlah 685.787 jiwa terdapat 21.626 Rumah Tangga Miskin (RTM). Sedangkan jumlah Rumah Tangga Miskin di Kota Batam sampai dengan Juni 2006 bertambah menjadi 33.422 Rumah Tangga Miskin.

Dalam rangka pelaksanaan program Nasional dalam penanggulangan kemiskinan di Kota Batam telah dilakukan penyaluran dana Subsidi Langsung Tunai (SLT) dan Kartu Kompensasi BBM (KKBBM) kepada 33.422 RTM di Kota Batam.

Peningkatan kesejahteraan masyarakat secara umum dilaksanakan melalui pemberdayaan, kesempatan kerja dan berusaha, peningkatan akses masyarakat produksi, mengembangkan potensi dan peluang agar masyarakat dapat keluar dari kondisi kemiskinan tersebut.

\subsection{PENGARUH PERKEMBANGAN EKONOMI TERHADAP}




\section{KESEJAHTERAAN MASYARAKAT}

Tingkat Perkembangan Ekonomi Kota Batam berpengaruh signifikan terhadap tingkat kesejahteraan masyarakat adalah diterima. Hasil analisis PLS menghasilkan koefisien jalur 0,0500 dengan $p$-value $=0.000$, dengan demikian diputuskan signifikan. Berarti terdapat pengaruh signifikan antara tingkat perkembangan ekonomi terhadap tingkat kesejahteraan masyarakat Kota Batam.

Pada tahun 2005, tingkat pertumbuhan ekonomi Kota Batam tumbuh sebesar 8,3 $\%$. Tingkat Pertumbuhan ekonomi ini berdampak pada penyerapan tenaga kerja pada tahun 2005 sebesar 221,391 tenaga kerja. Penyerapan tenaga kerja berdampak pada kesejahteraan masyarakat yaitu mengurangi tingkat pengangguran yang pada akhirnya akan menambah pendapatan masyarakat. Adanya korelasi antara perkembangan ekonomi dengan kemampuan daerah akan berdampak pada belanja publik yang berorientasi pada kesejahteraan masyarakat, seperti pengadaan sekolah, Puskemas dan sarananya.

Semakin membaiknya perkembangan Ekonomi Makro diperkirakan akan mendorong peningkatan kinerja perekonomian tahun 2006 sampai dengan tahun 2011, terutama jika didukung dengan sejumlah kebijakan struktural, seperti bidang perburuhan, investasi dan supremasi hukum.

Membaiknya indikator ekonomi yang diperkirakan masih terus berlangsung hingga tahun depan akan menciptakan ekspektasi positif para pelaku usaha dan terus mendorong pulihnya fungsi intermediasi. Sementara itu, stimulus fiskal dan adanya kepastian status Batam akan memberikan dampak multiplier diberbagai sektor perekonomian.

Secara keseluruhan pertumbuhan ekonomi Kota Batam dari tahun 2006 sampai dengan tahun 2011 diprediksikan akan mencapai kisaran antara 9,17 sampai dengan 11,37 persen. Ini bisa terjadi apabila kerja keras pemerintah baik Pemko Batam maupun Otorita Batam yang mampu bersinergi didalam menciptakan peningkatan pembangunan ekonomi.

Peningkatan Makro ekonomi yang digambarkan oleh salah satu indikatornya yaitu pertumbuhan ekonomi akan sangat berimbas kepada sistem investasi dimana di prediksikan peluang investasi tahun 2006 sampai dengan 2011 akan menunjukkan 
kenaikan yang cukup signifikan. Pada tahun 2006 diperkirakan sebesar US\$ 572,61 juta , sehingga tahun 2011 diharapkan akan mencapai US\$2.699,02 juta.

Kenaikan investasi yang diharapkan tumbuh positif ini tidak terlepas dari peran swasta dan investor luar negeri. Peran swasta ini khususnya di Batam merupakan perpanjangan tangan dari para investor luar negeri. Faktor keamanan baik internal maupun eksternal di Batam merupakan kondisi awal yang dibutuhkan oleh para investor. Dengan iklim investasi di Batam yang kondusif ini, tentu sangat membantu pemerintah, dan beberapa investor swasta baik dari dalam dan luar negeri untuk bersepakat kembali menanamkan investasinya di Batam.

Dengan memperhatikan kecenderungan ini upaya meningkatkan investasi tampaknya harus pula disertai dengan penajaman strategi kebijakan didalam penyusunan skala prioritas yang tepatguna. Hal ini sangat terkait dengan pembangunan ekonomi khususnya peningkatan sektor industri yang menjadi primadona Batam.

Skala prioritas yang mendesak yang perlu menjadi perhatian pemerintah dalam rangka peningkatan investasi di Batam yaitu pemerintah harus komit dalam menetapkan status kewilayahan Batam, memperbaiki kondisi ketenaga kerjaan, dimana jumlah penggangguran di Batam terus meningkat dikarenakan jumlah angkatan kerja yang tidak sebanding dengan lapangan kerja yang tersedia.

\section{PENUTUP}

\subsection{Kesimpulan}

Dari analisis dan pembuktian baik secara kualitatif tersebut dapat disusun kesimpulan dan saran sebagai berikut :

1. Kemampuan Pemerintah Kota Batam berpengaruh signifikan terhadap Kesejahteraan masyarakat adalah diterima. Hasil analisis PLS menghasilkan koefisien jalur 0,0501 dengan $\mathrm{p}$-value $=0.000$, dengan demikian diputuskan signifikan. Berarti terdapat pengaruh negatif signifikan antara Tingkat kemampuan pemerintah terhadap kesejahteraan masyarakat, dimana bila tingkat tingkat kemampuan pemerintah meningkat maka akan diikuti oleh kenaikan tingkat kesejahteraan masyarakat kota Batam.

2. Tingkat Perkembangan Ekonomi Kota Batam berpengaruh signifikan terhadap tingkat kesejahteraan masyarakat adalah diterima. Hasil analisis PLS 
menghasilkan koefisien jalur 0,0501 dengan $p$-value $=0.000$, dengan demikian diputuskan signifikan. Berarti terdapat pengaruh signifikan antara tingkat perkembangan ekonomi terhadap tingkat kesejahteraan masyarakat Kota Batam.

3. Tingkat kemampuan pemerintah berpengaruh signifikan terhadap tingkat perkembangan ekonomi. Hasil analisis PLS menghasilkan koefisien jalur 0,0991 dengan $p$-value $=0.0001$, dengan demikian diputuskan signifikan. Berarti terdapat pengaruh signifikan antara tingkat kemampuan pemerintah terhadap perkembangan ekonomi di kota Batam.

\subsection{Saran}

Untuk lebih meningkatkan kualitas pembangunan pemerintah terhadap kesejahteraan masyarakat kota batam, berikut adalah saran-saran yang direkomendasikan :

1. Belanja modal Pemerintah Kota batam diharapkan ke depan lebih tepat sasaran yang mempunyai multiffier effect langsung kepada kesejahteraan masyarakat seperti kebijakan dana bantuan bergulir kepada pengusaha kecil dan menengah

2. Membangun sarana dan prasarana fisik bagi masyarakat yang dapat menstimulasi kegiatan ekonomi masyarakat dan membuka akses kepada sektor pendidikan dan kesehatan

3. Pemerintah Kota Batam harus berupaya untuk mengembangkan sektor lain yang di dalam Produk Domestik Regional Bruto (PDRB) porsinya masih sangat kecil yairu pertanian, pertambangan dan angkutan agar dampaknya dapat dirasakan oleh masyarakat langsung

\section{DAFTAR PUSTAKA}

Grindele, Marilie, 1980. Politics and Policy Implementation in the Third World, , New Jersey : Princenton Unversity Press

BAPPEKO Batam, 1995, Implementasi Kebijakan Pembangunan Sosial Ekonomi di Wilayah Hinterland Kotamadya Batam, Batam : Bappeko Batam

BAPPEKO Batam, 2005, Batam Dalam Angka 2005. Batam : Bappeko Batam

Otorita Batam, 2004. Laporan Perekonomian 2004. Batam : Otorita Batam 
Basyiah, Ali. 1993. Konsep Dasar Perencanaan Pembangunan di Daerah., Jakarta : Bappenas

Baum, Warren C. and Tolbert, Stokes M.2006. Investasi Dalam Pembangunan. Jakarta : UI Press

Nurdin, Thamrin. 1993. Profil Sumber Daya dan Kemiskinan Komunitas Desa Nelayan, Padang : FAPERTA Universitas Andalas,

Gie, Kwik Kian, 1995. Dasar-dasar Ekonomi Perusahaan, Yogyakarta : Gramedia Pustaka Umum,

Gie, Kwik Kian.1996. Praktek Bisnis dan Orientasi Ekonomi Indonesia. Jakarta : Gramedia

Todaro, Michael P.2000. Pembangunan Ekonomi di Dunia Ketiga. Jilid 1, Edisi Ketujuh. Jakarta : Penerbit Erlangga

Thoha, Miftah. 1991. Beberapa Aspek kebijaksanaan Birokrasi. Yogyakarta : PT. Media Widya Mandala

Hunger, J. David \& Thomas L. Whelen.2001. Manajemen Strategis. Yogyakarta : Penerbit Andi

Jhingan, M.L. 2000. Ekonomi Pembangunan dan Perencanaan. Jakarta : PT. Raja Grafisindo

Tjiptoherijanto, Prijono. 1997. Migrasi, Urbanisasi dan Pasar Kerja di Indonesia. Jakarta : Ul Press

Gemmel, Norman. 1992. IImu Ekonomi Pembangunan. Jakarta : LP3ES

Pappas, James L.1995. Ekonomi Manajerial. Jakarta : Binarupa Aksara

Fishlow, Albert. 1980. Rich and Poor Nations in the World Economic. McGrawHill Book Company, New York

Arief, Sritua. 1998. Teori dan Kebijaksanaan Pembangunan. Jakarta, CIDES

Arief, Sritua,1993. Pemikiran Pembangunan dan Kebijaksanaan Ekonomi. Jakarta, Lembaga Riset Pembangunan

Wie, Thee Kian. 2004. Pembangunan, Kebebasan dan Mukjizat Orde Baru, Jakarta : Freedom Institute

Harun, Hamrolie. 2005. Analisis Ketersediaan Dana Pembangunan Daerah, Yogyakarta : BPFE

Sen, Amartya. 2006. Kekerasan dan Iusi Tentang Identitas, Jakarta : Marjin Kiri 